\title{
Research, misconduct and Congress
}

\author{
A private conference ten days ago seems chiefly to have demonstrated that there is some way to go \\ before researchers learn to live with - or placate - their lawmakers.
}

\section{Washington}

A CONFERENCE ten days ago at the Banbury Center at the Cold Spring Harbor Laboratory, with the curious title "The Ethos of Scientific Research", should probably be considered a valuable milepost showing how far the present debate about issues of scientific misconduct has come. Scientists, members of congressional staffs, a few journal editors and others who have contributed ideas for coping with the misconduct problem spent a day and a half in a meeting that seems to have been informative, but punctuated with episodic incredulity as scientists and legislative staffs alike learned how divergent their views can be. That is why cynics may choose to observe that this milestone also shows how far the debate still has to go.

The very mention of the word misconduct in scientific or congressional circles these days generates a hysterical craving for confidentiality by insiders to the process. But keeping a lid on such controversial issues is virtually impossible, and although the Banbury meeting was closed to the press, participants were willing, and in some cases anxious, to discuss their impressions afterwards.

The scientists in attendance were a stellar lot: James Watson, director of the Cold Spring Harbor Laboratory, Harvard's Walter Gilbert and Mark Ptashne, Rockefeller's Norton Zinder and Eric Kandel and Richard Axel from Columbia, to name a few. The names from Congress were less familiar, as only staff and no congressmen themselves attended, prompting one scientist to grumble that "we send them our first team, and they don't send theirs".

If there was ever hope that a consensus would emerge on handling scientific misconduct, that hope was not realized. What is agreed is simply that there is a problem whose scale or even seriousness is unknown. Although most research organizations and federal agencies would maintain that the number of cases of misconduct is small, there is little empirical evidence to back that up. But the reality now is that the size of the problem is no longer a crucial question; people in Congress see a problem, so there is one. Even if the scientific community could respond with carefully planned studies proving that misconduct is a negligible problem, until the political winds change it would not make much difference.
The easy approach, and one which would in general be pleasing to researchers, goes something like this. Congress has rightly identified a problem in the practice of science, the scientific community is appropriately grateful and will now take care of it if it is left alone.

But Congress has, with good reason, become wary of petitioners making "trust me" arguments. Washington is full of special pleaders on behalf of industries, agriculture and the armed services, to list but a few. And dealing with misconduct is an unpleasant task for all concerned, as the recent investigation of the Cell paper (see page 490) proves. No institution has shown much aptitude for conducting these investigations, and the National Institutes of Health (NIH) are no exception. The issues to be decided are not in question: a mechanism must be developed to determine when charges deserve investigation, to protect the rights of both accuser and accused, to carry out the investigation in a thorough and speedy way and to determine what punishment should be dealt to those found guilty.

The American Association of Universities has proposed a framework for such investigations that universities would in the first instance undertake (see Nature 337, 196; 19 January 1989), but there is a legitimate fear that universities would lose some of their collegiate character if they were assigned the role of policeman for their own research communities.

According to the Health Research Extension Act of 1985, those applying for federal research funds must guarantee that their institutions have mechanisms to deal with accusation of misconduct, but a report prepared by the Office of the Inspector General of the Department of Health and Human Services found that only 22 per cent of institutions receiving NIH grants have such procedures in place.

The Public Health Service has also served notice that it is considering new regulations that would spell out the responsibilities of institutions receiving federal research money. In an advance notice of proposed rulemaking in the 19 September issue of the Federal Register, the service raised the possibility of an office of scientific integrity to review all charges of misconduct and to determine what action would be most appropriate. A similar idea was incorporated into proposed legislation that circulated at the end of the last congressional session.
Although the legislation was never formally proposed last year, it is an active subject for discussion once again this year.

The need for the scientific community to work with Congress is at present complicated by poor relationships between scientists and congressional staffs, especially those staff members working for investigation and oversight subcommittees. The role of these committees is not to draft legislation or to appropriate money, but to ensure that laws are being implemented as Congress intended, and that money is being spent in a reasonable and appropriate fashion. But the Banbury conference - with the exception of Watson and Gilbert who communicated genuine concern for the issue - seems to have been marked either by arrogance or hostility or both on the part of some researchers towards these staffers, which does the former little credit.

Walter Stewart, who has temporarily left his NIH laboratory to work for the House of Representatives Energy and Commerce investigation subcommittee, came in for a particularly hard time from the researchers present. Stewart has incurred researchers' wrath for his investigations of alleged scientific fraud, investigations that have been marked at times by an almost religious fervour. Indeed, at the Banbury meeting, Stewart astounded participants by equating the moral taint of scientific fraud with that of the Holocaust. Although his point was that responsibility for identifying and tackling problems falls on everyone's shoulders, the idea that an incorrect scientific paper, even one written with knowing deception, can be in any way compared with the slaughter of 6 million people suggests that his enthusiasm for his work has exceeded reasonable bounds; he may no longer be a credible force in these investigations.

Congress has already served notice that it will continue to hold oversight investigations on this issue. And the scope of its interest appears to be broadening. In addition to the legislation that may emerge on misconduct as such, there may also, for example, be new laws explicitly forbidding researchers from accepting federal money to work on projects that may benefit companies in which they have a financial interest. The principle seems to be that, as spending on science grows, Congress will take an increasingly close look at how that money is spent - and by whom. 